\title{
PERBANDINGAN UNDANG-UNDANG NOMOR 3 TAHUN 1997 TENTANG PENGADILAN ANAK DENGAN UNDANG-UNDANG NOMOR 11 TAHUN 2012 TENTANG SISTEM PERADILAN PIDANA ANAK DALAM PEMERIKSAAN PERKARA ANAK DI PENGADILAN ANAK
}

\author{
Armanila Febri \\ Fakultas Hukum Universitas Riau \\ Email : neela_febri@ymail.com \\ Gusliana H.B. dan Davit Ramadhan \\ Fakultas Hukum Universitas Riau
}

\begin{abstract}
Children are people who have physical or mental limitations. Limitation understand everything, tends to bring negative influences into themselves and can cause it to do damage (juvenile delinquency) or even become perpetrators of delinquency (a criminal offense). Law No. 3 of 1997 on Juvenile Justice (Juvenile Court Act), in principle, was born to protect and nurture children in conflict with the law $(A B H)$. However, it was legally incapable angle Court Law provide legal protection against the $A B H$. Thus was born the amount of number 11 of 2012 on the Criminal Justice System Child (Law SPPA) to replace the Juvenile Justice Act. In the case of change of the Act there are striking differences in issues related to children in the examination of the case law SPPA. The purpose of this paper are: first, to determine the child's examination of the case in court demanding the setting $A B H$ Court Law Act with SPPA angle. Second, to determine the advantages and disadvantages of the examination of cases in court, according to Law $A B H$ juvenile justice law with Law SPPA.
\end{abstract}

Keywords: Comparative, investigation, Case, Children in conflict with the law $(A B H)$, Juvenile Justice

\section{abstrak}

Anak adalah orang yang memiliki keterbatasan fisik atau mental. Batasan memahami segala sesuatu, cenderung untuk membawa pengaruh negatif menjadi diri dan dapat menyebabkan ia berbuat kerusakan (kenakalan remaja) atau bahkan menjadi pelaku kenakalan (tindak pidana). UndangUndang Nomor 3 tahun 1997 tentang Pengadilan Anak (UU Pengadilan Anak), pada prinsipnya, lahir untuk melindungi dan memelihara anak yang berkonflik dengan hukum $(\mathrm{ABH})$. Namun, ternyata secara hukum UU 
Pengadilan angle tidak mampu memberikan perlindungan hukum terhadap ABH. Maka lahirlah jumlah nomor 11 tahun 2012 tentang Sistem Peradilan Pidana Anak (UU SPPA) untuk menggantikan Undang-Undang Pengadilan Anak. Dalam hal pergantian UU ada perbedaan mencolok dalam isu-isu yang berhubungan dengan anak dalam pemeriksaan SPPA kasus hukum. Tujuan dari penulisan ini yakni: pertama, untuk menentukan pemeriksaan anak dari kasus pengaturan $\mathrm{ABH}$ di Pengadilan menuntut UU Pengadilan UU dengan angle SPPA. Kedua, untuk menentukan keuntungan dan kerugian dari pemeriksaan kasus $\mathrm{ABH}$ di Pengadilan menurut UU pengadilan anak UU dengan UU SPPA.

Kata Kunci: Perbandingan, Investigasi, Kasus, Anak-anak yang berkonflik dengan hukum (ABH), Pengadilan Anak

\section{A. Pendahuluan}

Anak merupakan amanah dan karunia Tuhan Yang Maha Esa yang memiliki harkat dan martabat serta merupakan bagian dari generasi muda penerus cita-cita perjuangan bangsa di masa yang akan datang. Setiap anak memiliki harkat dan martabat yang di lindungi oleh hukum. Perlindungan ini perlu karena anak merupakan bagian masyarakat yang memiliki keterbatasan secara fisik dan mentalnya. ${ }^{1}$ Oleh sebab itu, anak memerlukan pembinaan dan perlindungan dalam rangka menjamin pertumbuhan dan perkembangan fisik, mental, dan sosial secara seimbang.

Secara Internasional, telah diatur dengan tegas bentuk perlindungan terhadap anak. Bentuk perlindungan terhadap anak dapat dilihat dari beberapa Konvensi Internasional tentang perlindungan terhadap anak, salah satunya yaitu Konvensi Perserikatan Bangsa- Bangsa mengenai Hak Anak atau (Convention on the Rights of the Child) Tahun 1989 yang mengemukakan prinsip-prinsip umum perlindungan anak, yaitu non diskriminasi, kepentingan terbaik bagi anak, kelangsungan hidup dan tumbuh kembang, dan menghargai partisipasi anak.

Dalam konvensi hak-hak anak juga diatur mengenai prinsip perlindungan khusus terhadap anak. Hal ini disebabkan dalam tahap perkembangan, anak-anak akan mempelajari apa yang dilihat, didengar, dan dirasakan. Oleh karena itu, anak memerlukan pembinaan, bimbingan khusus agar dapat berkembang fisik, mental dan spiritualnya secara maksimal. ${ }^{2}$

Salah satu prinsip perlindungan khusus yang diatur dalam konvensi tersebut adalah perlindungan terhadap anak yang berhadapan dengan hukum

\footnotetext{
1 Marliana, Peradilan Pidana Anak di Indonesia (Pengembangan Konsep Diversi dan Restrorative Justice), Refika Aditama, Bandung : 2009, hlm.42.

${ }^{2}$ Darwan Prinst, Hukum Anak Indonesia, Citra Aditya Bakti, Bandung : 1997, hlm. 4.
} 
(children in conflict with the Law). Lebih lanjut diatur dalam PeraturanPeraturan Minimum Standar Perserikatan Bangsa-Bangsa mengenai Administrasi Peradilan bagi Anak (Beijing Rules). Dimana prinsip Beijing Rules mengatur anak pelaku tindak pidana dihindarkan dari pidana penjara. Penjatuhan pidana merupakan upaya terakhir, karena penjatuhan pidana terhadap pelaku anak berakibat anak masuk lembaga pemasyarakatan anak. ${ }^{3}$

Di Negara Indonesia sendiri mengenai perlindungan hukum terhadap harkat dan martabat anak terdapat dalam konstitusi yakni Undang-Undang Dasar 1945. Pasal 28 B Ayat (2) dikatakan: "setiap anak berhak atas keberlangsungan hidup, tumbuh dan berkembang, serta berhak atas perlindungan dari kekerasaan dan diskriminasi”.

Selanjutnya dalam hukum positif Indonesia, perlindungan hukum terhadap hak-hak anak dapat ditemui di berbagai peraturan perundangundangan seperti yang tertuang dalam Keputusan Presiden Nomor 36 Tahun 1990 pada tanggal 25 Agustus 1990 yang merupakan ratifikasi dari Konvensi PBB tentang Hak-Hak Anak (Convention on the Rights of the Child ); Undang-Undang Nomor 4 Tahun 1979 tentang Kesejahteraan Anak; dan Undang-Undang Nomor 23 Tahun 2002 tentang Perlindungan Anak. ${ }^{4}$

Mengenai prinsip perlindungan khusus terhadap anak yang berhadapan dengan hukum yang tertuang dalam konvensi hak-hak anak telah diatur dalam Undang-Undang Nomor 3 Tahun 1997 tentang Pengadilan Anak. Hal ini terdapat pada poin menimbang yang pada prinsipnya menjelaskan tentang penyelenggaraan pengadilan bagi anak perlu dilakukan secara khusus. Hal ini dikarenakan anak adalah kelompok rentan secara fisik maupun mental.

Sebagaimana dalam Undang-Undang Nomor 23 Tahun 2002 tentang Perlindungan Anak dikatakan, anak adalah seseorang yang yang belum berusia 18 (delapan belas) tahun, termasuk anak dalam kandungan. Dalam hal ini pengertian anak mencakup situasi dimana seseorang yang dalam kehidupannya mencapai tumbuh kembangnya, membutuhkan bantuan orang lain (orang tua atau orang lain). ${ }^{5}$

Hal tersebut disebabkan anak memiliki keterbatasan dalam memahami apa yang ia pelajari sehingga cenderung membawa pengaruh negatif kedalam dirinya. Pada akhirnya dapat menyebabkan anak melakukan kenakalan (Juvenile delinquency) atau menjadi pelaku (delinquency).

Juvenile delinquency adalah suatu tindakan atau perbuatan yang melanggar norma, baik norma hukum maupun norma-norma sosial yang

\footnotetext{
${ }^{3}$ Marliana, op.cit., hlm. 12.

${ }^{4}$ Nashriana, Perlindungan Hukum Pidana Bagi Anak di Indonesia, Raja Grafindo Persada, Jakarta : 2001, hlm. 13.

${ }^{5}$ Sholeh Soeaidy dan Zulfikar, Dasar Hukum Perlindungan Anak, Novindo Pustaka mandiri, Jakarta: 2001 , hlm. 3.
} 
dilakukan oleh anak-anak usia muda. Oleh sebab itu, hal tersebut cenderung untuk dikatakan sebagai kenakalan anak dari pada kejahatan anak, terlalu ekstrim rasanya seorang anak yang melakukan tindak pidana dikatakan sebagai penjahat, sementara kejadiannya adalah proses alami yang tidak boleh setiap manusia mengalami kegoncangan semasa menjelang kedewasaan. $^{6}$

Apalagi posisi anak dalam melakukan tindak pidana tidaklah sama dengan orang dewasa yang sudah memiliki akal dan pengalaman, di mana anak berada pada taraf yang belum mampu memperjuangkan sesuatu yang menjadi haknya. Secara hukum Undang- Undang Nomor 3 Tahun 1997 tentang Pengadilan Anak lahir untuk memberikan perlindungan hukum terhadap anak yang berhadapan dengan hukum. Namun, secara yuridisformil ternyata Undang-Undang Nomor 3 Tahun 1997 tentang Pengadilan Anak tidak cukup memberikan jaminan perlindungan hukum terhadap anak yang berhadapan dengan hukum.

Sebagaimana Menteri Hukum dan HAM Amir Syamsuddin mengatakan Undang- Undang Nomor 3 Tahun 1997 tidak lagi sesuai dengan perkembangan dan kebutuhan hukum masyarakat. Undang-Undang Nomor 3 tahun 1997 tentang Pengadilan Anak belum secara komprehensif memberikan perlindungan kepada anak yang berhadapan dengan hukum. ${ }^{7}$

Salah satu kelemahan Undang-Undang ini adalah inkonsistensinya terhadap isi Peraturan Minimum Standar Perserikatan Bangsa-Bangsa mengenai Administrasi Peradilan bagi Anak (Beijing Rules). Di mana di dalam aturan 11 Beijing Rules telah diatur dengan tegas ketentuan mengenai penanganan perkara anak yang berhadapan dengan hukum, namun tidak dimuat dalam Undang-Undang Nomor 3 Tahun 1997 tentang Pengadilan Anak. Sehingga, secara tidak langsung telah terjadi pengabaian prinsip kepentingan terbaik bagi anak yang termuat di dalam Konvensi Hak-Hak Anak dan Undang-Undang Nomor 23 Tahun 2002 tentang Perlindungan Anak.

Sebagaimana data Departemen Hukum dan HAM tahun 2008 jumlah anak yang berhadapan dengan Hukum 5760 anak di berbagai LAPAS di Indonesia, sekitar $57 \%$ bercampur dengan orang dewasa. ${ }^{8}$ Berdasarkan data tersebut jelas terlihat bahwa masih banyak anak-anak yang berhadapan dengan hukum belum memperoleh perlindungan yang memadai. Bahkan tidak sedikit anak yang berkasus tersebut di sidang ke pengadilan atas kejahatan ringan. Misalnya kasus sepuluh orang anak laki-laki menjalani

\footnotetext{
${ }^{6}$ Wagiati Soetedjo, Hukum Pidana Anak, Refika Aditama,Bandung : 2006, hlm.11.

7 http: politik.news.viva.co.id/news/read/332348-8-isu-krusial-di-uu-sistem-peradilan-anak. ( Diakses pada hari sabtu, 05 Januari 2013 pukul 11.34 wib ).

${ }^{8}$ http: Press Release: SKB Penanganan Anak Yang Berhadapan Dengan Hukum.(Diakses pada hari sabtu, 06 Januari 2013 pukul 11.32 wib ).
} 
sidang anak di Pengadilan Negeri Tangerang, Banten, yang didakwa dengan kasus berjudi dengan taruhan uang koin Rp. 500, ironisnya anak yang masih berumur 11 (sebelas) tahun ikut disidang. ${ }^{9}$

Selanjutnya kasus pencurian sandal jepit oleh AAL yang berusia 15 tahun. AAL sendiri terjerat kasus hukum pada November Tahun 2010 yang dituduh seorang bintara polisi telah mencuri sandal merek Eiger miliknya. Kasusnya kemudian mulai disidangkan pada awal Desember 2011 lalu. ${ }^{10}$ Padahal tindak pidana pencuriannya sebenarnya bukan tindak pidana berat, namun anak tersebut tetap diproses di pengadilan. Hasil kajian dan pemetaan serta fakta di berbagai lapas anak di lapangan menunjukkan situasi dan kondisi anak yang berhadapan dengan hukum sangat memprihatinkan. ${ }^{11}$

Sangat ironis, hal tersebut tentu sangat berdampak buruk pada anak tersebut, karena anak butuh bermain, belajar di sekolah. Sementara ia tersebut harus menjalani proses peradilan dan harus menjalani tahanan. Panjang proses peradilan yang dijalani anak tersangka pelaku kejahatan, sejak proses penyidikan di kepolisian sampai selesai menjalani hukuman di lembaga pemasyarakatan merupakan gambaran kesedihan seorang anak.

Kejadian selama proses peradilan menjadi pengalaman tersendiri bagi kehidupan anak yang sulit terlupakan. Pengalaman demikian akan membekas dalam diri mereka. ${ }^{12}$ Demi memperhatikan kelangsungan kehidupan anak untuk masa yang akan datang, maka dilakukanlah perubahan terhadap Undang-Undang Nomor 3 Tahun 1997 tentang Pengadilan Anak menjadi Undang-undang Nomor 11 Tahun 2012 tentang Sistem Peradilan Pidana Anak.

Dengan dikeluarkannnya Undang-Undang Nomor 11 Tahun 2012 tentang Sistem Peradilan Pidana Anak ada perbedaan mencolok terkait masalah pemeriksaan perkara anak di Pengadilan. Berdasarkan adanya perbedaan tersebut, penulis termotivasi untuk membandingkan UndangUndang 3 Tahun 1997 tentang Pengadilan Anak dengan Undang-Undang Nomor 11 Tahun 2012 tentang Sistem Peradilan Pidana Anak dalam hal pemeriksaan perkara yang dilakukan oleh anak di Pengadilan Anak.

Berdasarkan dari uraian latar belakang tersebut di atas, maka penulis ingin mengupas beberapa permasalahan yang dijadikan objek di dalam penelitian ini. Yang menjadi rumusan masalah adalah sebagai berikut: 1). Bagaimana pengaturan pemeriksaan perkara anak yang berhadapan dengan hukum di pengadilan anak di dalam Undang-Undang Nomor 3 Tahun 1997 tentang Pengadilan Anak dengan Undang-Undang Nomor 11 Tahun 2012

\footnotetext{
9 "Usia Minimal Diproses Pidana," Gatra, 16 Maret 2011, hlm.96.

${ }^{10} \mathrm{http}: / /$ radarlampung.co.id/read/radar/berita-foto/44717-bocah-aal-setelah-kasus-pencuriansandal-jepit- menasional.( Diakses pada hari sabtu, 20 Oktober 2012 pukul 6.49 wib ).

${ }^{11} \mathrm{http}$ : Press Release: SKB Penanganan Anak Yang Berhadapan Dengan Hukum.

${ }^{12}$ Marliana, Op.,Cit. hlm.16
} 
tentang Sistem Peradilan Pidana? dan 2). Apakah kelemahan dan kelebihan pemeriksaan perkara anak yang berhadapan dengan hukum di pengadilan anak di dalam Undang-Undang Nomor 3 Tahun 1997 tentang Pengadilan Anak dengan Undang-Undang Nomor 11 Tahun 2012 tentang Sistem Peradilan Pidana Anak?

\section{B. Pembahasan}

1. Pengaturan Pemeriksaan Perkara Anak yang Berhadapan dengan Hukum di Pengadilan Anak di dalam Undang-Undang Nomor 3 Tahun 1997 tentang Pengadilan Anak dengan Undang-Undang Nomor 11 Tahun 2012 tentang Sistem Peradilan Pidana

a. Pengaturan Pemeriksaan Perkara Anak yang Berhadapan dengan Hukum di Pengadilan Anak di dalam Undang-Undang Nomor 3 Tahun 1997 tentang Pengadilan Anak

Ketika seorang anak yang terlibat dalam perbuatan pidana maka ia akan menjalani proses pemeriksaan awal di kepolisian oleh Penyidik, kemudian diteruskan ke Jaksa Penuntut Umum dan selanjutnya pemeriksaan persidangan oleh Hakim anak. ${ }^{13}$ Proses hukum di atas merupakan pelaksanaan dari sistem peradilan pidana. Sistem peradilan pidana merupakan pelaksanaan dari proses hukum yang berada dalam satu sistem terdiri dari subsistem yang saling berhubungan.

Pada dasarnya, sistem peradilan pidana (SPP) atau Criminal Justice System dikemukakan pertama kali di Amerika Serikat oleh pakar hukum pidana dan para ahli dalam Criminal Justice Science. ${ }^{14}$ Menurut Mardjono Reksodiputro, sistem peradilan pidana merupakan sistem dalam suatu masyarakat untuk menanggulangi masalah kejahatan, menanggulangi bertujuan mengendalikan kejahatan agar berada dalam batas- batas toleransi dan menyelesaikan sebagian besar laporan ataupun keluhan masyarakat yang menjadi korban kejahatan dengan mengajukan pelaku kejahatan ke sidang pengadilan untuk diputus bersalah serta mendapat pidana. ${ }^{15}$

Berdasarkan perspektif peradilan pidana anak, maka subsistem dalam sistem peradilan pidana anak mempunyai kekhususan, dimana terhadap anak sebagai suatu kajian hukum yang khusus, membutuhkan aparat-aparat yang secara khusus diberi wewenang untuk menyelenggarakan proses peradilan pidana terhadap anak yang berhadapan dengan hukum. ${ }^{16}$ Berdasarkan analisa penulis, hal tersebut didasarkan pada pendekatan filosofi terhadap usia

\footnotetext{
13 Marliana, Peradilan Pidana Anak di Indonesia ( Pengembangan Konsep Diversi dan Restrorative Justice), Refika Aditama, Bandung : 2009, hlm.133.

${ }^{14}$ Nashriana, Perlindungan Hukum Pidana Bagi Anak di Indonesia, Raja Grafindo Persada, Jakarta : 2001, hlm.101.

${ }^{15}$ Marliana, Op., Cit. hlm.5.

${ }^{16}$ Nashriana, Op.,Cit.hlm.106.
} 
pelaku dimana anak berada pada taraf yang belum mampu memperjuangkan apa yang menjadi haknya. Apalagi mengingat sifat dan keadaan psikologis anak dalam beberapa hal tertentu seperti proses peradilan pidana maka diperlukan perlakuan yang khusus agar tindakan-tindakan selama dalam proses peradilan pidana tidak mengganggu fisik maupun psikis anak. Oleh sebab itu polisi, jaksa, dan hakim yang menangani pidana anak tersebut adalah polisi, jaksa, dan hakim anak.

Dalam penelitian ini penulis meneliti bagaimana penanganan perkara anak yang berhadapan dengan hukum $(\mathrm{ABH})$ di Pengadilan. Di mana penanganan perkara ABH dalam Undang-Undang Nomor 3 Tahun 1997 tentang Pengadilan Anak di tingkat Pengadilan memakai prosedur formal yakni secara litigasi atau melalui pemeriksaan di sidang pengadilan.

Adapun tahapan dalam proses peradilan pidana yaitu tahap prajudikasi (sebelum sidang peradilan) meliputi penyidikan dan penyelidikan, judikasi (selama sidang peradilan) meliputi pemeriksaan dan pembuktian tuntutan jaksa dan paskajudikasi (setelah sidang peradilan) meliputi pelaksanaan keputusan yang telah ditetapkan dalam persidangan seperti penempatan terpidana dalam lembaga pemasyarakatan. ${ }^{17}$

Mengenai ketentuan pemeriksaan perkara anak yang berhadapan dengan hukum di dalam Undang-Undang Nomor 3 Tahun 1997 tentang Pengadilan Anak diatur secara khusus dalam BAB IV Paragraf 4 Pasal 55 sampai dengan 59, namun dalam pasal-pasal sebelumnya juga sebagian sudah menyebutkan mengenai ketentuan pemeriksaan perkara anak di tingkat pengadilan. Secara keseluruhan ketentuan pemeriksaan perkara anak di muka pengadilan adalah sebagai berikut :

1) Hakim, Penuntut Umum dan Penasihat Hukum tidak memakai toga Pasal 6 menyatakan : "Hakim, Penuntut Umum, Penyidik dan Penasehat Hukum, serta petugas yang lainnya dalam Sidang Anak tidak memakai toga atau pakaian dinas".

Dalam pemeriksaan perkara anak nakal, para pejabat yang disebutkan dalam pasal 6 di atas tidak boleh memakai toga, termasuk panitera yang membantu hakim tidak memakai jas. Semua pakaian kebesaran tersebut tidak dipakai pejabat pemeriksa, hal ini dimaksudkan agar dalam persidangan tidak menimbulkan kesan menakutkan atau menyeramkan terhadap anak yang diperiksa. Selain itu agar dengan pakaian biasa dapat menjadikan persidangan berjalan dengan lancar dan penuh kekeluargaan. ${ }^{18}$ Terlebih lagi agar tidak menjadi peristiwa yang mengerikan bagi anak.

2) Disidang dengan Hakim Tunggal

\footnotetext{
${ }^{17}$ Ibid. hlm.5

${ }^{18}$ Ibid. hlm. 140.
} 
Pada prinsipnya pemeriksaan di pengadilan dilakukan dengan hakim majelis, namun pemeriksaan sidang anak dilakukan dengan hakim tunggal (Pasal 11 Ayat (1) UU Pengadilan Anak). Dengan hakim tunggal, bertujuan agar sidang anak dapat diselesaikan dengan cepat. ${ }^{19}$ Memang pada prinsipnya bahwa penyelesaian perkara anak dapat dilakukan dengan waktu singkat/cepat agar anak tidak berlama-lama mendapat perlakuan terkait pemberian sanksi terhadap kenakalan yang telah dilakukannya. ${ }^{20}$

Perkara anak yang disidangkan dengan hakim tunggal adalah perkaraperkara pidana yang ancaman hukumannya lima tahun ke bawah dan pembuktiannya mudah atau tidak sulit. Apabila tindak pidananya diancam dengan hukuman penjara diatas lima tahun dan pembuktiannya sulit, maka berdasarkan Pasal 11 Ayat (2) UU Pengadilan Anak, perkara tersebut diperiksa dengan hakim majelis.

Pengaturan hakim tunggal dalam UU Pengadilan Anak berbeda dengan ketentuan yang diatur dalam Undang-Undang Nomor 14 Tahun 1970 tentang Pokok- Pokok Kekuasaan Kehakiman (yang kini diubah melalui Undang-Undang Nomor 35 Tahun 1999). Dalam Pasal 15 Ayat (1) disebutkan bahwa, "Semua pengadilan memeriksa dan memutuskan dengan sekurang-kurangnya 3 (tiga) orang hakim, kecuali apabila undang-undang menentukan lain". Kecuali disini berarti membuka kemungkinan untuk pemeriksaan oleh hakim tunggal.

Di tingkat banding maupun di tingkat kasasi, hakim yang memeriksa dan memutus perkara anak nakal sama dengan ditingkat Pengadilan Negeri, yaitu dengan hakim tunggal (Pasal 14 dan Pasal 18 UU Pengadilan Anak). ${ }^{21}$

3) Pemeriksaan perkara Anak dilakukan dalam sidang tertutup

Dalam penjelasan Pasal 8 UU Pengadilan Anak disebutkan bahwa pemeriksaan perkara anak nakal dilakukan secara tertutup dan wajib dihadiri orang tua, wali, atau orang tua asuh berdasarkan pertimbangan agar tercipta suasana tenang dan penuh dengan kekeluargaan sehingga anak dapat mengutarakan segala peristiwa dan segala perasaannya secara terbuka dan jujur selama sidang berjalan. Kemudian digunakan singkatan dari nama anak, orang tua, wali, atau orang tua asuhnya dimaksudkan agar identitas anak dan keluarganya tidak menjadi berita umum yang akan lebih menekan perasaan serta mengganggu kesehatan mental anak. ${ }^{22}$

Mengenai kewajiban kehadiran orang tua, wali, atau orang tua

\footnotetext{
19 Gatot Supramono, Surat Dakwaan dan Putusan Hakim, Yang Batal Demi Hukum, Djambatan, Jakarta : 1991, hlm. 61.

${ }^{20}$ Nashriana, Op., Cit. hlm.141.

${ }^{21}$ Nashriana, op., cit. hlm.142.

${ }^{22}$ Wagiati Soetedjo, Op.,Cit. hlm.35.
} 
asuhnya juga terdapat dalam Pasal 55 yang menyebutkan: "Dalam perkara Anak Nakal sebagaimana dimaksud dalam Pasal 1 angka 2, Penuntut Umum, Penasihat Hukum, Pembimbing Kemasyarakatan, orang tua, wali, atau orang tua asuh dan saksi, wajib hadir dalam Sidang Anak".

4) Laporan Pembimbing Kemasyarakatan

Sesuai Pasal 56 UU Pengadilan Anak, sebelum sidang dibuka, hakim memerintahkan kepada Pembimbing Kemasyarakatan agar menyampaikan laporan hasil penelitian kemasyarakatan (LITMAS) mengenai anak yang bersangkutan. Ini berarti pembimbing kemasyarakatan menyampaikan laporannya secara tertulis dan kelak bila diperlukan pembimbing kemasyarakatan dapat memberikan kesaksian di di depan Pengadilan Anak.

Maksud diberikannya laporan sebelum sidang dibuka, adalah agar cukup waktu bagi hakim untuk memelajari laporan hasil penelitian kemasyarakatan itu. Oleh karena itu, laporan tidak diberikan pada saat sidang berlangsung, tetapi beberapa waktu sebelumnya.

Hal tersebut bertujuan karena latar belakang kehidupan anak mempengaruhi pertimbangan hukum bagi hakim. Di dalam praktek ternyata Case Study sangat membantu hakim dalam menjatuhkan keputusannya. Di mana Case Study ini membuka jalan bagi hakim guna lebih dalam mengenal pribadi anak sehingga dalam memberikan keputusannya akan lebih terarah serta sesuai dengan apa yang dibutuhkan anak.

Pembimbing kemasyarakatan yang dimaksud adalah pembimbing kemasyarakatan pada Balai Pemasyarakatan di wilayah hukum Pengadilan Negeri setempat. Apabila di wilayah hukum Pengadilan Negeri tidak terdapat Balai Pemasyarakatan, maka menurut Pasal 12 Ayat (2) Keputusan Menteri Kehakiman No.M.02. PW.07.10 Tahun 1997, hakim dapat memerintahkan pembimbing kemasyarakatan dari anak yang bersangkutan untuk membuat laporan hasil penelitian kemasyarakatan pada Balai Pemasyarakatan terdekat. ${ }^{23}$

Adapun laporan hasil penelitian kemasyarakatan (Pasal 56 Ayat (2) UU Pengadilan Anak) sekurang-kurangnya memuat hal-hal sebagai berikut :

a) data individu anak dan data keluarga anak yang bersangkutan; dan

b) kesimpulan atau pendapat dari pembimbing kemasyarakatan yang membuat laporan hasil-hasil penelitian kemasyarakatan. Sehubungan dengan hal diatas, laporan hasil penelitian kemasyarakatan berisikan halhal berikut: ${ }^{24}$

i. identitas: klien, orang tua, dan susunan keluarga dalam satu rumah;

ii. masalah sosialnya;

iii. riwayat hidup klien;

${ }^{23}$ Ibid. hlm. 37.

${ }^{24}$ Nashriana, op., cit. hlm.144-145. 
iv. tanggapan klien terhadap masalah yang dialaminya;

v. keadaan keluarga;

vi. keadaan lingkungan masyarakat;

vii. tanggapan pihak keluarga, masyarakat, dan pemerintah setempat; dan

viii. kesimpulan dan saran.

5) Pembukaan Sidang Anak (Terdakwa didampingi Orang Tua, Penasehat Hukum, dan Pembimbing Kemasyarakatan)

Sebagaimana Pasal 57 Ayat (1) UU Pengadilan Anak menyatakan : "Setelah Hakim membuka persidangan dan menyatakan sidang tertutup untuk umum, terdakwa dipanggil masuk beserta orang tua, wali, atau orang tua asuh, Penasihat Hukum, dan Pembimbing Kemasyarakatan".

Selama dalam persidangan terdakwa didampingi oleh orang tua, wali, atau orang tua asuh, penasehat hukum, dan pembimbing kemasyarakatan (Pasal 57 Ayat (2) UU Pengadilan Anak). Menurut praktek, hakim lalu memeriksa identitas terdakwa, dan setelah itu hakim mempersilahkan jaksa penuntut umum membacakan surat dakwaannya. Setelah itu, terdakwa atau penasehat hukum diberikan kesempatan untuk mengajukan tangkisan atau eksepsi atas dakwaan jaksa penuntut umum. ${ }^{25}$

\section{6) Pemeriksaan Saksi}

Pada asasnya setiap saksi didengar di persidangan dihadiri oleh terdakwa, dengan maksud agar terdakwa mengetahui apa yang diterangkan oleh saksi dalam mengungkap terjadinya peristiwa pidana di mana terdakwa yang didakwa sebagai pelakunya. Sehubungan dengan itu, terdakwa mempunyai kesempatan untuk menyanggah keterangan saksi tentang hal-hal yang tidak benar dari keterangan itu.

Orang yang diajukan sebagai saksi, terutama diambil dari orang-orang yang kebetulan berada disekitar tempat kejadian, dengan tujuan agar mereka mudah mengungkapkan jalannya peristiwa pidana. Sebelum memberikan keterangan di persidangan, saksi diwajibkan mengangkat sumpah terlebih dahulu, bahwa ia akan menerangkan dengan benar dari apa yang dilihat dan didengar atau dialami sendiri.

Apabila saksi tidak menerangkan dengan benar dan telah diperingatkan oleh hakim yang memimpin sidang pengadilan, tetapi ternyata saksi tetap pada keterangannya, maka berdasarkan Pasal 174 Ayat (2) KUHAP hakim ketua sidang karena jabatannya atau atas permintaan penuntut umum atau terdakwa, dapat memerintahkan supaya saksi tersebut ditahan dan selanjutnya dituntut dengan dakwaan sumpah palsu. Saksi yang demikian dapat dipidana berdasarkan Pasal 242 KUHP. ${ }^{26}$

\footnotetext{
${ }^{25}$ Ibid. hlm. 146.

${ }^{26}$ Ibid. hlm. 147.
} 
Dalam perkara anak, pada tingkat pemeriksaan saksi dapat tidak dihadiri oleh terdakwa. Sesuai Pasal 58 Ayat (1) UU Pengadilan Anak, pada waktu memeriksa saksi, hakim dapat memerintahkan agar terdakwa dibawa keluar ruang sidang.

Hal ini dimaksud untuk menghindari adanya hal yang mempengaruhi jiwa anak. Di mana tidak semua anak yang mempunyai sikap mental yang kuat untuk bisa mendengarkan secara langsung keterangan orang lain yang mengungkapkan perbuatannya yang kurang atau tidak baik. Bagi yang tidak bisa mendengarkan dan ini tetap dipaksakan, akan berakibat tidak baik bagi perkembangan anak yang bersangkutan.

Sedangkan orang tua, wali atau orang tua asuhnya, penasehat hukum, dan pembimbing kemasyarakatan berdasarkan Pasal 58 Ayat (2) disebutkan: "Pada waktu pemeriksaan saksi sebagaimana dimaksud dalam ayat (1), orang tua, wali, atau orang tua asuh, Penasihat Hukum, dan Pembimbing Kemasyarakatan tetap hadir".

7) Putusan Hakim

Pasal 59 UU Pengadilan Anak, disebutkan bahwa:

a. Sebelum mengucapkan putusannya, Hakim memberikan kesempatan kepada orang tua, wali, atau orang tua asuh untuk mengemukakan segala hal ikhwal yang bermanfaat bagi anak;

b. Putusan sebagaimana dimaksud dalam ayat (1) wajib mempertimbangkan laporan penelitian kemasyarakatan dari Pembimbing Kemasyarakatan; dan

c. Putusan pengadilan wajib diucapkan dalam sidang terbuka untuk umum.

Mengenai Pasal 59 Ayat (2), di mana dalam putusannya, hakim wajib mempertimbangkan laporan hasil penelitian kemasyarakatan yang disampaikan oleh pembimbing kemasyarakatan, karena laporan hasil penelitian kemasyarakatan tersebut merupakan gambaran keadaan si anak. Oleh sebab itu, hakim wajib memperhatikan dan mempertimbangkan Case Study dari terdakwa, agar hakim dalam memberikan putusannya sesuai dengan kebutuhan anak tersebut. Apabila ketentuan ini tidak dipenuhi, mengakibatkan putusan batal demi hukum. Dalam hal ini Case Study dapat menentukan hukuman manakah yang sebaiknya bagi anak, mengingat hakim dapat memilih dua kemungkinan pada Pasal 22 Undang-Undang Nomor 3 Tahun 1997, yaitu anak dapat dijatuhi pidana (bagi anak yang telah berumur diatas 12 sampai 18 tahun) atau tindakan (bagi anak yang masih berumur 8 sampai 12 tahun).

\section{b. Pengaturan Pemeriksaan Perkara Anak yang Berhadapan dengan Hukum di Pengadilan Anak di dalam Undang-Undang Nomor 11 Tahun 2012 tentang Sistem Peradilan Pidana Anak}


Berdasarkan prosedur formal dari sistem peradilan pidana di Indonesia maka setiap orang yang melakukan tindak pidana akan diselesaikan secara hukum ke sidang pengadilan dan apabila terbukti bersalah maka akan di pidana. Terhadap cara penyelesaian seperti di atas tidak dapat sepenuhnya diterapkan apabila yang melakukan tindak pidana tersebut adalah anak. Hal ini disebabkan anak adalah seseorang yang memiliki kejiwaan yang labil, dan tindakan yang dilakukannya tersebut tidak bisa dikatakan sebagai kejahatan, melainkan kenakalan karena tindakannya lahir dari kondisi psikologis yang tidak seimbang, disamping itu anak tersebut juga tidak sadar apa yang ia lakukan. ${ }^{27}$

Perilaku kenakalan yang dilakukan oleh anak walau kadangkala sama dengan kejahatan yang dilakukan orang dewasa, tetapi bukan berarti harus diselesaikan seperti layaknya orang dewasa diproses melalui peradilan pidana karena mengingat sifat dan keadaan psikologisnya dalam beberapa hal tertentu memerlukan perlakuan khusus serta perlindungan yang khusus pula, terutama terhadap tindakan-tindakan yang pada hakekatnya dapat merugikan perkembangan mental maupun jasmani anak. ${ }^{28}$ Oleh sebab itu menurut hemat penulis, peradilan pidana perlu dijauhkan dari anak. Peradilan pidana harusnya dijadikan upaya terakhir dalam penanganan perkara anak yang berhadapan dengan hukum, karena bisa saja situasi dan kondisi selama proses peradilan menimbulkan efek buruk pada anak dan mungkin bisa menjadikan anak lebih nakal lagi. Padahal sistem peradilan pidana anak bertujuan untuk mencegah seorang anak terjerumus kembali ke dalam perbuatan yang buruk. Namun ternyata proses peradilan pidanalah yang menjadikan anak melakukan kejahatan kembali.

Bertitik tolak dari filosofis pelakunya adalah anak maka perlu adanya pembedaan perlakuan penanganan anak yang berhadapan dengan hukum. Sehingga di dalam pembentukan Undang-Undang Nomor 11 Tahun 2012 dilakukan pembaharuan terhadap penanganan perkara anak yang berhadapan dengan hukum. Di mana pemerintah sebagai penyelenggara perlindungan terhadap anak berupaya melakukan semaksimal mungkin kebijakan penegakan hukum (law enforcemen policy) dengan cara memperbaharui kebijakan penanggulangan kejahatan (criminal policy). ${ }^{29}$

Menurut Pieter Hoefnagels, keterlibatan masyarakat dalam kebijakan penanggulangan kejahatan (criminal policy) sangat penting, karena kebijakan penanggulangan kejahatan merupakan usaha yang rasional dari masyarakat sebagai reaksi terhadap kejahatan. Secara garis besar upaya penanggulangan kejahatan dibagi dua, yaitu jalur "penal" (hukum pidana) dan jalur "non penal" (di luar hukum pidana). Penanggulangan kejahatan

\footnotetext{
${ }^{27}$ Wagiati Soetedjo, op.cit., hlm.12

${ }^{28}$ Nashriana, Op.,cit. hlm. 34.

${ }^{29}$ Marliana, Op., cit. hlm.13.
} 
melalui jalur penal menyangkut bekerjanya fungsi aparatur penegak hukum dalam sistem peradilan pidana terdiri dari kepolisian, kejaksaan, pengadilan, dan lembaga pemasyarakatan. Penanggulangan lewat jalur penal lebih menitikberatkan pada sifat "represive" (penindasan/ pemberantasan/ penumpasan) sesudah kejahatan terjadi. Sedangkan jalur non penal lebih menitikberatkan pada sifat "preventive" (pencegahan/ penangkalan/ pengendalian) sebelum kejahatan terjadi. ${ }^{30}$

Adapun ketentuan pemeriksaan perkara anak yang berhadapan dengan hukum di pengadilan diatur dalam Pasal 52 sampai dengan Pasal 62 UndangUndang Nomor 11 Tahun 2012 tentang Sistem Peradilan Pidana Anak (UU SPPA). Dalam hal ini mekanisme penanganan perkara anak yang berhadapan dengan hukum ada dua jalur. Dimana penyelesaian jalur pertama yaitu diupayakan proses penanganan perkara anak yang berhadapan dengan hukum di luar jalur pengadilan (non litigasi), yakni melalui diversi berdasarkan pendekatan keadilan restroratif. Selanjutnya, penyelesaian jalur kedua adalah melalui jalur formal (litigasi), yaitu melalui pemeriksaan di pengadilan.

Secara keseluruhan pemeriksaan perkara anak yang berhadapan dengan hukum di pengadilan adalah sebagai berikut:

\section{1) Penyelesaian melalui jalur diversi (non litigasi)}

Pasal 52 Ayat (2) dikatakan : "Hakim wajib mengupayakan diversi paling lama 7 (tujuh) hari setelah ditetapkan oleh Ketua Pengadilan Negeri sebagai Hakim".

Selanjutnya penyelesaian terhadap perkara anak yang berhadapan dengan hukum lewat jalur diversi juga disebutkan sebelumnya pada Pasal 5 Ayat (3) dan Pasal 7 Ayat (1). Di mana dalam Pasal 5 Ayat (3) dikatakan, "Dalam Sistem Peradilan Pidana Anak sebagaimana dimaksud pada ayat (2) huruf a dan huruf b wajib diupayakan diversi".

Dalam hal ini Pasal 5 Ayat (2) huruf b ini adalah persidangan anak di pengadilan. Selanjutnya pada Pasal 7 Ayat (1) yakni, "Pada tingkat penyidikan, penuntutan, dan pemeriksaan perkara Anak di Pengadilan Negeri wajib di upayakan diversi".

Berdasarkan ketentuan yang diatur dalam Pasal 5 Ayat (3), Pasal 7 Ayat (1) dan Pasal 52 Ayat (2) ini jelas bahwa hakim harus terlebih dahulu mengupayakan penyelesaian perkara terdakwa anak melalui jalur diversi. Adapun UU Sistem Peradilan Pidana Anak mengatur penyelesaian lewat jalur diversi ini dengan mengutamakan pendekatan keadilan restroratif (Pasal 5 UU SPPA).

Di mana pengertian keadilan restroratif berdasarkan Pasal 1 angka 6 adalah : "penyelesaian perkara tindak pidana dengan melibatkan pelaku,

${ }^{30}$ Ibid, hlm.16. 
korban, keluarga pelaku/korban, dan pihak lain yang terkait untuk bersamasama mencari penyelesaian yang adil dengan menekankan pemulihan kembali pada keadaan semula, dan bukan pembalasan".

Adapun ketentuan pelaksanaan diversi adalah sebagai berikut :

a) Syarat-Syarat Pelaksanaan Diversi

Adapun syarat-syarat pelaksanaan diversi adalah :

i. Tindak pidana yang dilakukan anak pelaku dibawah 7 (tujuh) tahun

Pasal 7 Ayat (2) huruf a dikatakan: "Diversi sebagaimana dimaksud pada ayat (1) dilaksanakan dalam hal tindak pidana yang dilakukan diancam dengan pidana penjara di bawah 7 (tujuh) tahun".

ii. Pelaku bukan recidivist

Pasal 7 Ayat (2) huruf b disebutkan : "Diversi sebagaimana dimaksud pada ayat (1) dilaksanakan dalam hal tindak pidana yang dilakukan. bukan merupakan pengulangan tindak pidana”.

iii. Kategori tindak pidana

Hakim dalam melakukan diversi harus mempertimbangkan kategori tindak pidana (Pasal 9 Ayat (1) poin a). Berdasarkan penjelasan Pasal 9 Ayat (1) poin a bahwa ketentuan ini merupakan indikator bagi hakim di dalam menerapkan diversi terhadap penyelesaian perkara anak. Di mana semakin rendah ancaman pidana maka semakin tinggi prioritas diversi. Diversi tidak untuk terhadap pelaku tindak pidana serius misalnya, pembunuhan, pemerkosaan, pengedar narkoba, dan terorisme, yang mana kesemua tindak pidana tersebut diancam diatas 7 (tujuh) tahun.

iv. Umur Anak

Hakim dalam melakukan diversi harus mempertimbangkan umur anak pelaku tindak pidana (Pasal 9 Ayat (1) poin b). Pada penjelasan poin $b$ ini, umur anak termasuk prioritas dalam pemberian diversi. Apabila semakin muda umur anak pelaku tindak pidana maka akan semakin tinggi prioritas penyelesaian melalui jalur diversi.

v. Hasil penelitian kemasyarakatan dari Balai Pemasyarakatan

Hal ini juga akan menjadi indikator bagi hakim dalam menentukan penyelesaian diversi. Dimana hasil penelitian kemasyarakatan merupakan latar belakang kehidupan anak. Dalam hasil penelitian tersebut akan terlihat sebab-sebab anak melakukan tindak pidana apakah karena kesengajaan, keterpaksaan, ataupun lain-lain. Inilah yang akan menjadi pertimbangan hakim.

vi. Dukungan lingkungan keluarga dan masyarakat.

vii. Kesepakatan diversi harus melalui persetujuan korban/keluarga korban. Dalam Penjelasan Pasal 9 Ayat (2) disebutkan bahwa ketentuan mengenai diversi harus ditanyakan terlebih dahulu kepada korban apakah korban setuju atau tidak dilakukan diversi. Kemudian mengenai "persetujuaan keluarga korban" apabila korban dalam hal ini dibawah 
umur. Dalam Pasal 9 Ayat (2) ada pengecualian, yakni diversi dapat dilakukan tanpa persetujuan korban terhadap:

a. tindak pidana yang berupa pelanggaran;

b. tindak pidana ringan;

c. tindak pidana tanpa korban; atau

d. nilai kerugian korban tidak lebih dari nilai upah minimum provinsi.

b) Tata Cara Pelaksanaan Diversi

Adapun prosedur pelaksanan diversi yang diatur di dalam UU Sistem Peradilan Pidana Anak dilaksanakan paling lama 30 (tiga puluh) hari setelah ketua pengadilan negeri menetapkan hakim pemeriksa perkara anak tersebut (Pasal 52 Ayat (3) UU SPPA). Sedangkan proses diversi sendiri dilaksanakan di ruang mediasi pengadilan negeri (Pasal 52 Ayat (4) UU SPPA). Mengenai tata cara pelaksanaan diversi diatur dalam Pasal 8 :

"(1) Proses diversi dilakukan melalui musyawarah dengan melibatkan anak dan orang tua/walinya, korban dan/atau orang tua/walinya, Pembimbing Kemasyarakatan, dan Pekerja Sosial Profesional berdasarkan pendekatan Keadilan Restoratif;

(2) Dalam hal diperlukan, musyawarah sebagaimana dimaksud pada ayat (1) dapat melibatkan Tenaga Kesejahteraan Sosial, dan/atau masyarakat;

(3) Proses diversi wajib memperhatikan:

a. kepentingan korban;

b. kesejahteraan dan tanggung jawab anak;

c. penghindaran stigma negatif;

d. penghindaran pembalasan;

e. keharmonisan masyarakat; dan

f. kepatutan, kesusilaan, dan ketertiban umum".

Dalam Penjelasan Umum UU Sistem Peradilan Pidana Anak disebutkan bahwa proses diversi ini harus bertujuan terciptanya keadilan restroratif, baik bagi anak pelaku maupun bagi korban. Diversi berdasarkan keadilan restroratif yaitu sebuah penyelesaian perkara anak pelaku tindak pidana, dengan melibatkan semua pihak (korban, anak, keluarga korban/pelaku, penegak hukum, dan masyarakat). Di mana semua pihak bersama-sama mengatasi masalah serta menciptakan suatu kewajiban untuk membuat segala sesuatunya menjadi lebih baik, yakni dengan cara mencari solusi memperbaiki, rekonsiliasi, dan menentramkan hati serta tidak berdasarkan pembalasan.

c) Hasil Kesepakatan Diversi

Apabila proses diversi berhasil mencapai kesepakatan, maka hasil kesepakatan diversi dituangkan dalam bentuk kesepakatan diversi (Pasal 12 Ayat (1)). Kemudian Hakim akan menyampaikan berita acara diversi beserta 
kesepakatan diversi kepada ketua pengadilan negeri untuk dibuat penetapan (Pasal 52 Ayat (5)).

Jangka waktu hakim menyampaikan hasil kesepakatan diversi kepada Ketua Pengadilan Negeri yakni paling lama 3 (tiga) hari terhitung sejak kesepakatan dicapai untuk memperoleh penetapan (Pasal 12 Ayat (2)). Sedangkan penetapan dilakukan dalam waktu paling lama 3 (tiga) hari terhitung sejak diterimanya kesepakatan diversi (Pasal 12 Ayat (3)). Adapun hasil kesepakatan diversi dapat berbentuk, antara lain:

i. perdamaian dengan atau tanpa ganti kerugian;

ii. penyerahan kembali kepada orang tua/wali;

iii. keikutsertaan dalam pendidikan atau pelatihan di lembaga pendidikan atau lembaga penyelenggaraan kesejahteraan sosial (LPKS) paling lama 3 (tiga) bulan; atau

iv. pelayanan masyarakat (Pasal 11).

d) Pengawasan Proses Diversi

Mengenai pengawasan proses diversi terdapat dalam Pasal 14 UU

Sistem Peradilan Pidana Anak yang menyebutkan :

“(1) Pengawasan atas proses diversi dan pelaksanaan kesepakatan yang dihasilkan berada pada atasan langsung pejabat yang bertanggung jawab di setiap tingkat pemeriksaan.

(2) Selama proses diversi berlangsung sampai dengan kesepakatan diversi dilaksanakan, Pembimbing Kemasyarakatan wajib melakukan pendampingan, pembimbingan, dan pengawasan.

(3) Dalam hal kesepakatan diversi tidak dilaksanakan dalam waktu yang ditentukan, Pembimbing Kemasyarakatan segera melaporkannya kepada pejabat yang bertanggung jawab sebagaimana dimaksud pada ayat (1).

(4) Pejabat yang bertanggung jawab sebagaimana dimaksud pada ayat (3) wajib menindaklanjuti laporan dalam waktu paling lama 7 (tujuh) hari”.

Adapun dalam penjelasan Pasal 14 Ayat (1), bahwa pengawasan terhadap proses diversi dan kewenangan pelaksaksanaan atas hasil kesepakatan di tingkat pengadilan adalah tanggung jawab dari ketua pengadilan. Adapun penjelasan Pasal 14 Ayat (2), dimana pembimbing kemasyarakatan wajib melakukan pendampingan, pembimbingan, dan pengawasan terhadap anak pelaku selama proses diversi berlangsung dan sampai pada hasil kesepakatan dilaksanakan.

Sedangkan apabila kesepakatan diversi tidak dilaksanakan dalam waktu yang ditentukan, Pembimbing Kemasyarakatan segera melaporkannya kepada ketua pengadilan negeri, dan dalam waktu paling lama 7 (tujuh) hari ketua pengadilan wajib menindaklanjuti laporan tersebut. 


\section{2) Penyelesaian Jalur Pengadilan (Litigasi)}

Perkara anak yang berhadapan dengan hukum akan lanjut ke tahap persidangan apabila dalam penyelesaian secara diversi tidak berhasil dilaksanakan (Pasal 52 Ayat (6) UU SPPA). Adapun ketentuan pemeriksaan perkara anak yang berhadapan dengan hukum di dalam Undang-Undang Nomor 11 Tahun 2012 tentang Sistem Peradilan Pidana Anak diatur secara khusus dalam BAB III Bagian Keenam Pasal 53 sampai dengan Pasal 62, sedangkan ketentuan pemeriksaan perkara anak di muka pengadilan adalah sebagai berikut :

1) Disidang dalam ruang sidang khusus anak (Pasal 53 Ayat (1) UU SPPA)

Anak yang berhadapan dengan hukum di sidang di dalam ruang sidang khusus anak di dalam lingkup peradilan umum. Berdasarkan Pasal 53 Ayat (1) bahwa ruang sidang anak harus dipisah dengan ruang sidang orang dewasa. Waktu sidang Anak didahulukan dari waktu sidang orang dewasa (Pasal 53 Ayat (3) UU SPPA)

2) Perkara anak yang berhadapan dengan hukum disidang dengan hakim tunggal

Sebagaimana yang disebutkan dalam Pasal 44 Ayat (1), 47 Ayat (1) dan Pasal 50 Ayat (1), bahwa sidang perkara anak yang berhadapan dengan hukum pada tingkat pertama, banding, maupun kasasi diperiksa dengan hakim tunggal. Perkara anak yang disidangkan dengan hakim tunggal adalah perkara-perkara pidana yang ancaman hukumannya di bawah 7 (tujuh) tahun ke bawah dan pembuktiannya mudah atau tidak sulit. Apabila tindak pidananya diancam dengan hukuman penjara 7 (tujuh) tahun atau lebih serta pembuktiannya sulit, maka berdasarkan Pasal 44 Ayat (2), 47 Ayat (2) dan Pasal 50 Ayat (2), perkara tersebut pada setiap tingkat pemeriksaan diperiksa dengan hakim majelis.

3) Pemeriksaan perkara Anak dilakukan dalam sidang tertutup (Pasal 54 UU SPPA)

Mengenai pemeriksaan perkara anak yang dilakukan dalam sidang tertutup berdasarkan Pasal 54 terdapat pengecualian yakni dalam pembacaan putusan maka sidang terbuka untuk umum. Dalam penjelasan pasal ini juga menyebutkan bahwa dalam hal tertentu dan dipandang perlu, hakim dapat menetapkan pemeriksaan perkara dilakukan secara terbuka, tanpa mengurangi hak anak dan hakim dalam menetapkan hal tersebut melihat dari sifat dan keadaan perkara yang akan diperiksa misalnya perkara pelanggaran lalu lintas atau pemeriksaan perkara yang dilakukan di tempat perkara.

4) Terdakwa Wajib didampingi Orang Tua/Pendamping, Penasehat Hukum, dan Pembimbing Kemasyarakatan (Pasal 55 Ayat (1) UU SPPA)

Meskipun pada prinsipnya tindak pidana yang dilakukannya adalah 
tanggung jawab dari pelaku, namun karena dalam hal ini pelaku/terdakwanya adalah anak maka anak tidak dapat dipisahkan dengan kehadiran orang tua/walinya. Adapun konsekuensi dalam Ayat (3) pasal ini adalah apabila hakim tidak melaksanakan ketentuan tersebut di atas maka sidang anak batal demi hukum.

\section{5) Pembukaan Sidang}

Setelah hakim membuka persidangan dan menyatakan sidang tertutup untuk umum, anak dipanggil masuk beserta orang tua/wali, advokat atau pemberi bantuan hukum lainnya, dan Pembimbing Kemasyarakatan (Pasal 56 UU SPPA). Kemudian dilanjutkan dengan pembacaan surat dakwan.

6) Penyampaian Laporan Hasil Penelitian Kemasyarakatan Tanpa Kehadiran anak terdakwa (Pasal 57 Ayat (1) UU SPPA)

Dalam penjelasan pasal ini disebutkan bahwa ketentuan pembacaan laporan hasil penelitian kemasyaraktan "tanpa kehadiran anak" bertujuan untuk menghindari adanya hal yang mempengaruhi jiwa anak korban dan/atau anak saksi. Adapun laporan hasil penelitian kemasyarakatan tersebut berisikan:

i. data pribadi anak, keluarga, pendidikan, dan kehidupan sosial;

ii. latar belakang dilakukannya tindak pidana;

iii. keadaan korban dalam hal ada korban dalam tindak pidana terhadap tubuh atau nyawa;

iv. hal lain yang dianggap perlu;

v. berita acara diversi; dan

vi. kesimpulan dan rekomendasi dari pembimbing kemasyarakatan (Pasal 57 Ayat (2) UU SPPA).

7) Pemeriksaan Anak Korban \& Anak Saksi (Pasal 58 UU SPPA)

Pada saat memeriksa anak korban dan/atau anak saksi, hakim dapat memerintahkan agar anak terdakwa dibawa keluar ruang sidang (Pasal 58 Ayat (1)). Sementara orang tua/wali, advokat atau pemberi bantuan hukum lainnya, dan pembimbing kemasyarakatan tetap hadir (Pasal 58 Ayat (2)). Keterangan anak korban dan anak saksi dapat dilakukan di dalam persidangan maupun di luar persidangan. Sebagaimana pada ayat (3) dalam pasal ini disebutkan, bahwa apabila anak korban dan/atau anak saksi tidak dapat hadir untuk memberikan keterangan di depan sidang pengadilan, hakim dapat memerintahkan anak korban dan/atau anak saksi didengar keterangannya:

i. di luar sidang pengadilan melalui perekaman elektronik yang dilakukan oleh pembimbing kemasyarakatan di daerah hukum setempat dengan dihadiri oleh penyidik atau penuntut umum dan advokat atau pemberi bantuan hukum lainnya; atau

ii. melalui pemeriksaan langsung jarak jauh dengan alat komunikasi 
audiovisual dengan didampingi oleh orang tua/wali, pembimbing kemasyarakatan atau pendamping lainnya.

8) Putusan Hakim

Dalam Pasal 60 UU Sistem Peradilan Pidana Anak disebutkan:

(1) Sebelum menjatuhkan putusan, Hakim memberikan kesempatan kepada orang tua/wali dan/atau pendamping untuk mengemukakan hal yang bermanfaat bagi anak.

(2) Anak diberi kesempatan oleh hakim untuk menyampaikan pendapat tentang perkara yang bersangkutan.

(3) Hakim wajib mempertimbangkan laporan penelitian kemasyarakatan dari Pembimbing Kemasyarakatan sebelum menjatuhkan putusan perkara.

(4)Dalam hal laporan penelitian kemasyarakatan sebagaimana dimaksud pada ayat (3) tidak dipertimbangkan dalam putusan hakim, putusan batal demi hukum”.

Dalam penjelasan Pasal 60 Ayat (4) disebutkan bahwa dalam membuat putusan hakim harus mempertimbangkan hasil penelitian kemasyarakatan. Hal ini sangat perlu, karena laporan hasil penelitian kemasyarakatan tersebut berisikan latar belakang kehidupan anak dan mengapa anak tersebut melakukan tindak pidana. Berdasarkan hal tersebut hakim dapat menilai dan menentukan hukuman manakah yang cocok dan baik serta sesuai dengan kebutuhan terdakwa. Apabila dalam putusan hakim tidak mempertimbangkan laporan penelitian kemasyarakatan, maka putusan hakim batal demi hukum artinya putusan itu tidak memiliki kekuatan mengikat.

Pada waktu pembacaan putusan pengadilan, maka sidang yang terbuka untuk umum dan terdakwa boleh atau tidak menghadiri sidang (Pasal 61 Ayat (1)). Hal ini dimaksudkan agar siapa saja dapat menghadiri sidang dan mengetahui putusan. Bagi pihak media masa yang hadir dalam sidang anak harus merahasiakan identitas anak, anak korban, dan/atau anak saksi yakni dengan hanya menggunakan inisial tanpa gambar (Pasal 61 Ayat (2)). Hal ini bertujuan agar identitas anak yang berhadapan dengan hukum dan keluarganya tidak menjadi berita umum atau pembicaraan khalayak ramai sebab hal tersebut akan lebih menekan perasaan serta dapat menjadi beban mental anak.

Adapun hukuman yang dapat dijatuhkan oleh hakim kepada anak adalah berupa tindakan dan pidana.

c. Perbandingan Pemeriksaan Perkara Anak yang Berhadapan dengan Hukum di Pengadilan Anak di dalam Undang-Undang Nomor 3 Tahun 1997 tentang Pengadilan Anak dengan Undang-Undang 


\section{Nomor 11 Tahun 2012 tentang Sitem Peradilan Pidana Anak.}

Dalam menganai perkara anak yang berhadapan dengan hukum di Pengadilan, UU Pengadilan Anak hanya menerapkan aturan pemeriksaan secara formal yakni melalui proses persidangan, sementara di dalam UU Sistem Peradilan Pidana Anak sebelum melewati proses persidangan hakim wajib mengupayakan penyelesaian perkara anak secara diversi atau disebut juga penyelesaian perkara anak diluar pengadilan (informal). Sebagaimana yang disebutkan dalam Pasal 52 Ayat (2), bahwa: "Hakim wajib mengupayakan diversi paling lama 7 (tujuh) hari setelah ditetapkan oleh Ketua Pengadilan Negeri sebagai Hakim". berikut:

Adapun gambaran secara rinci mengenai diversi yakni sebagai

\section{1) Pengertian Diversi}

Dalam hal ini pengertian diversi adalah pengalihan penyelesaian perkara anak dari proses peradilan pidana ke proses di luar peradilan pidana (Pasal 1 angka 7 UU SPPA). Adapun UU Sistem Peradilan Pidana Anak mengatur penyelesaian lewat jalur diversi ini dengan mengutamakan pendekatan keadilan restroratif (Pasal 5 UU SPPA). Dimana pengertian keadilan restroratif berdasarkan Pasal 1 angka 6 adalah: "penyelesaian perkara tindak pidana dengan melibatkan pelaku, korban, keluarga pelaku/korban, dan pihak lain yang terkait untuk bersama-sama mencari penyelesaian yang adil dengan menekankan pemulihan kembali pada keadaan semula, dan bukan pembalasan".

Adapun konsep restroratif justice, menurut Tony Marshall adalah merupakan proses penyelesaian tindakan pelanggaran hukum yang terjadi dilakukan dengan membawa korban dan pelaku (tersangka) bersama-sama duduk dalam satu pertemuan untuk bersama-sama berbicara. Dalam pertemuan tersebut mediator memberikan kesempatan kepada pihak pelaku untuk memberikan gambaran yang sejelas-jelasnya mengenai tindakan yang telah dilakukannya. ${ }^{31}$ Pihak pelaku yang melakukan pemaparan sangat mengharapkan pihak korban untuk dapat menerima dan memahami kondisi dan penyebab mengapa pihak pelaku melakukan tindak pidana yang menyebabkan kerugian pada korban.

Selanjutnya dalam penjelasan pelaku juga memaparkan tentang bagaimana dirinya bertanggung jawab terhadap korban dan masyarakat atas perbuatan yang telah dilakukannya. Selama pihak pelaku memaparkan tentang tindakan yang telah dilakukannya dan sebab-sebab mengapa sampai tindakan tersebut dilakukan pelaku, korban wajib mendengarkan dengan teliti penjelasan pelaku. Untuk selanjutnya pihak korban dapat memberikan

\footnotetext{
${ }^{31}$ Marliana, op., cit. hlm. 180
} 
tanggapan atas penjelasan pelaku. Di samping itu, juga hadir pihak masyarakat yang mewakili kepentingan masyarakat. Wakil masyarakat tersebut memberikan gambaran tentang kerugian yang diakibatkan oleh telah terjadinya tindak pidana yang dilakukan oleh pelaku.

Dalam paparannya tersebut masyarakat mengharapkan agar pelaku melakukan suatu perbuatan atau tindakan untuk memulihkan kembali keguncangan/kerusakan yang telah terjadi karena perbuatannya. ${ }^{32}$ Ketentuan penyelesaian perkara anak secara diversi sama halnya dengan konsep pemikiran pakar hukum pidana Muladi. Menurut Muladi, model yang cocok untuk sistem peradilan pidana Indonesia adalah yang mengacu kepada daaddader strafrecht yang disebutnya sebagai model keseimbangan kepentingan. ${ }^{33}$ Model ini adalah model yang realistis yaitu yang memperhatikan berbagai kepentingan yang harus dilingkungi oleh hukum pidana, yaitu kepentingan negara, kepentingan umum, kepentingan individu, kepentingan pelaku tindak pidana dan kepentingan korban kejahatan.

\section{2) Tujuan Diversi}

Adapun sebab dilaksanakannya diversi dalam penanganan perkara anak adalah karena posisi anak dalam melakukan tindak pidana tidak sama dengan orang dewasa yang sudah mempunyai akal dan pengalaman, di mana anak berada pada taraf yang belum mampu mempertanggungjawabkan perbuatannya. Oleh sebab itulah, maka penggunaaan hukum pidana dalam penyelesaian masalah anak, agar dapat dibatasi atau dapat digunakan sebagai upaya terakhir. Hal ini melihat dampak dari proses pidana tersebut terhadap anak, sehingga sangat diperlukan adanya penerapan upaya restroratif justice yang merupakan bagian dari konsep diversi. Adapun yang menjadi tujuan pelaksanaan diversi adalah $:^{34}$

a) untuk menghindarkan anak dari penahanan;

b) untuk menghindari cap/label anak sebagai penjahat;

c) untuk mencegah pengulangan tindak pidana yang telah dilakukan oleh anak;

d) agar anak bertanggung jawab atas perbuatannya;

e) untuk melakukan intervensi-intervensi yang diperlukan bagi korban dan anak tanpa harus melalui proses formal;

f) menghindari anak mengikuti proses sistem peradilan; dan

g) menjauhkan anak dari pengaruh dan implikasi negatif dari proses peradilan.

\footnotetext{
${ }^{32}$ Ibid. hlm. 181 .

33 http://manunggalkusumawardaya.wordpress.com/2010/07/07/perlindungan-terhadap-anakyang- melakukan-tindak-pidana/. (Diakses pada hari rabu, 20 februari 2013 pukul 12.40 wib).

$34 \mathrm{http} / / /$ anjarnawanyep.wordpress.com/konsep-diversi-dan-restroratif-justice/ (diakses pada hari sabtu 8 Februari 2013, Pukul 15. 23 WIB)
} 
2. Kelemahan dan Kelebihan Pemeriksaan Perkara Anak yang Berhadapan dengan Hukum di Pengadilan Anak di dalam UndangUndang Nomor 3 Tahun 1997 tentang Pengadilan Anak dengan Undang-Undang Nomor 11 Tahun 2012 tentang Sistem Peradilan Pidana Anak

a. Kelemahan dan Kelebihan Pemeriksaan Perkara Anak yang Berhadapan dengan Hukum di Pengadilan Anak di dalam UndangUndang Nomor 3 Tahun 1997 tentang Pengadilan Anak

1) Kelemahan pemeriksaan perkara anak yang berhadapan dengan hukum di pengadilan anak di dalam Undang-Undang Nomor 3 Tahun 1997 tentang Pengadilan Anak

Adapun kelemahan pemeriksaan perkara anak dalam UU Pengadilan Anak ini adalah terletak pada mekanisme pemeriksaan perkara anak yang berhadapan dengan hukum. Di mana UU Pengadilan Anak hanya melihat bahwa cara penyelesaian yang terbaik dalam menangani perkara anak yang berhadapan dengan hukum harus di periksa secara formal, yakni melalui persidangan di pengadilan. Padahal persoalan kejahatan tidak hanya diarahkan pada penyelesaian jalur peradilan, tetapi bisa melalui non peradilan. ${ }^{35}$ Adapun kelemahan dari pemeriksaan secara formal (litigasi) adalah :

a) Prosesnya panjang dan biaya mahal

Lamanya proses persidangan seorang anak untuk dibuktikan bersalah atau tidaknya anak berada di dalam penahanan maksimal selama 3 (tiga) bulan. Untuk sampai pada tahapan pembacaan keputusan ada beberapa tahapan yang harus dilalui oleh anak dalam proses persidangan. Tahapan persidangan dimulai dengan pembukaan sidang pengadilan, di mana hakim memanggil terdakwa dan memeriksa identitas terdakwa dengan teliti sampai proses pembacaan putusan ada sekitar 11 kali sidang. ${ }^{36}$

Di samping prosesnya panjang kelemahan lain dari proses pemeriksaan perkara melalui litigasi adalah biaya relatif lebih besar dibandingkan dengan pemeriksaan di luar pengadilan, karena pemeriksaan di pengadilan lama dan terlalu banyak administrasinya sehingga pelaku harus mengeluarkan biaya banyak seperti biaya pengacara di setiap kali persidangan.

b) Anak kehilangan kebebasan akibat ditahan atau di jatuhi hukuman penjara

Hal ini dikarenakan pada dasarnya anak butuh bermain, belajar di

\footnotetext{
${ }^{35}$ Marliana, Op., cit. hlm.16

${ }^{36}$ Ibid. hlm 149.
} 
sekolah. Sementara panjangnya proses peradilan yang dijalani anak tersangka pelaku kejahatan, sejak proses penyidikan di kepolisian sampai selesai menjalani hukuman di lembaga pemasyarakatan merupakan gambaran kesedihan seorang anak. ${ }^{37}$ Gambaran kesedihan bagi anak di sini menunjukkan bahwa proses peradilan tersebut mengakibatkan anak akan kehilangan kebebasan dalam hidupnya. Hal ini dikarenakan umumnya penyelesaian perkara melalui proses peradilan akan berakhir pada pemidanaan ketika pelaku terbukti bersalah.

c) Anak Mengalami Beban Psikis

Kejadian selama proses peradilan menjadi pengalaman tersendiri bagi kehidupan anak yang sulit terlupakan. Pengalaman demikian akan membekas dalam diri mereka. ${ }^{38}$ Sebagaimana hasil kajian dan pemetaan serta fakta di berbagai lapas anak di lapangan menunjukkan situasi dan kondisi anak yang berhadapan dengan hukum sangat memprihatinkan. ${ }^{39}$

d) Penilaian/label jelek dari masyarakat (stigmasasi) terhadap anak terdakwa

Dalam hal ini masyarakat masih ada yang menilai anak yang pernah melalui proses sistem peradilan pidana sebagai akibat melakukan tindak pidana biasanya akan terlibat tindak pidana lain di masa yang akan datang. Stigmasasi tersebut sangat sulit dihilangkan dari pandangan masyarakat.

e) Sering terjadi pengulangan atau penghukuman kembali (reconviction rate)

Dalam kaitan ini, R.M. Jackson mengemukakan, bahwa pidana penjara termasuk jenis pidana yang relatif kurang efektif. Berdasarkan hasil studi perbandingan efektivitas pidana, angka perbandingan rata-rata pengulangan atau penghukuman kembali (reconviction rate) orang yang pertama kali melakukan kejahatan berbanding terbalik dengan usia pelaku. Revonviction rate yang tertinggi, terlihat pada anak-anak, yaitu mencapai 50 persen. Angka itu lebih tinggi lagi setelah orang dijatuhi pidana penjara dari pada pidana bukan penjara. ${ }^{40}$

2) Kelebihan pemeriksaan perkara anak yang berhadapan dengan hukum di pengadilan anak di dalam Undang-Undang Nomor 3 Tahun 1997 tentang Pengadilan Anak

UU Pengadilan Anak menentukan pemeriksaan perkara anak yang berhadapan dengan hukum melalui mekanisme formal yakni melalui pemeriksaan di sidang pengadilan. Adapun kelebihan pemeriksaan perkara anak yang

\footnotetext{
${ }^{37}$ Ibid. hlm.12.

${ }^{38}$ Marliana, Loc.cit.

${ }^{39}$ http: Press Release: SKB Penanganan Anak Yang Berhadapan Dengan Hukum.

${ }^{40}$ Ibid.
} 
berhadapan dengan hukum melalui persidangan adalah: ${ }^{41}$

a) Adanya kepastian hukum

Dengan diprosesnya suatu perkara di pengadilan, maka akan diperoleh kepastian hukum terhadap pelaku yang didakwa melakukan tindak pidana tersebut.

b) Memperoleh keadilan

Tujuan utama diprosesnya perkara di pengadilan adalah untuk memperoleh keadilan terhadap perbuatan pidana yang dilakukan seseorang.

c) Berfungsi sebagai upaya preventif

Artinya pemeriksaan di sidang pengadilan dapat menanggulangi kejahatan untuk yang akan datang. Di mana ketika masyarakat melihat seseorang yang melakukan tindak pidana kemudian disidang dan dihukum maka orang akan berfikir untuk melakukan tindak pidana.

d) Dapat berfungsi sebagai upaya represif

Penyelesaian perkara anak yang berkonflik dengan hukum melalui persidangan di pengadilan dapat menimbulkan efek jera kepada pelaku karena proses peradilan yang begitu panjang umumnya anak pelaku untuk kepentingan pemeriksaan pengadilan akan di tahan dan apabila terbukti bersalah ia akan di beri sanksi. Secara garis besar sanksi yang dapat dijatuhkan kepada anak yang telah melakukan kenakalan, terdiri dari dua, yaitu sanksi pidana dan sanksi tindakan. ${ }^{42}$

Adapun tujuan sanksi pidana adalah memberikan penderitaan kepada pelanggar supaya ia merasakan akibat perbuatannya sehingga ia jera untuk melakukan tindak pidana. Sedangkan sanksi tindakan adalah untuk mendidik anak pelaku tersebut, sehingga anak tersebut lebih mandiri, contohnya menyerahkan anak terdakwa kepada negara untuk mengikuti pendidikan, pembinaan dan latihan kerja.

b. Kelemahan dan Kelebihan Pemeriksaan Perkara Anak yang Berhadapan dengan Hukum di Pengadilan Anak di dalam UndangUndang Nomor 11 Tahunn 2012 tentang Sistem Peradilan Pidana Anak

1) Kelemahan pemeriksaan perkara anak yang berhadapan dengan hukum di pengadilan anak di dalam Undang-Undang Nomor 11 Tahun 2012 tentang Sistem Peradilan Pidana Anak

41 http://korandemokrasiindonesia.wordpress.com/2009/11/28/hukum-di-indonesi-hukumacara-pidana.( Diakses pada hari sabtu, 22 Maret 2013, pukul 12.16 wib).

${ }^{42}$ Nashriana, op., cit. hlm.80. 
UU Sistem Peradilan Pidana Anak menentukan bahwa sebelum melewati proses persidangan hakim wajib mengupayakan penyelesaian perkara anak secara diversi atau disebut juga penyelesaian perkara anak di luar pengadilan (informal) dengan cara restroratif justice. Adapun kelemahan pemeriksaan perkara anak secara diversi melalui restroratif justice adalah ${ }^{43}$ :

a) Tindak pidana yang dilakukan diancam dengan pidana berat

Terhadap kejahatan yang dilakukan pelaku merupakan kejahatan yang diancam dengan pidana berat, maka hal ini juga merupakan penyebab sulitnya diversi terlaksana. ${ }^{44}$ Sebagaimana yang disebutkan dalam Pasal 7 Ayat (2) huruf a : "Diversi sebagaimana dimaksud pada ayat (1) dilaksanakan dalam hal tindak pidana yang dilakukan diancam dengan pidana penjara di bawah 7 (tujuh) tahun".

Selanjutnya disebutkan dalam Pasal 9 Ayat (1) poin a disebutkan bahwa syarat terlaksananya diversi juga dilihat dari kategori tindak pidana yang dilakukan anak. Dalam Penjelasan Pasal 9 disebutkan bahwa ketentuan ini merupakan indikator bagi hakim dalam menerapkan diversi terhadap penyelesaian perkara anak.

Di mana semakin rendah ancaman pidana maka semakin tinggi prioritas diversi. Diversi tidak untuk terhadap pelaku tindak pidana serius misalnya, pembunuhan, pemerkosaan, pengedar narkoba, dan terorisme, yang mana ke semua tindak pidana tersebut diancam di atas 7 (tujuh) tahun.

b) Susah mendapatkan persetujuan korban/keluarga korban

Walaupun cara non litigasi bisa membuat anak pelaku tindak pidana terhindar dari berbagai efek buruk sanksi pidana, namun ternyata tak semua pihak menyepakatinya. Dalam hal ini biasanya pihak korban yang tidak menyepakati. Di mana tidak semua korban atau keluarga korban mau menerima cara penyelesaian non ligitasi. Pihak korban umumnya menghendaki agar pelaku dimasukkan penjara supaya jera. ${ }^{45}$

c) Kemampuan mediator sangat mempengaruhi keberhasilan proses restroratif justice

Pelaksanaan restroratif justice yang dilaksanakan dengan kurangnya pelatihan dalam mengatasi konflik dan teknik memfasilitasi/mediasi dan pelaksanaannya kurang sempurna akan menyebabkan kurangnya keberhasilan dalam pelaksanaan. Oleh karena itu, peran pelaksana restroratif

\footnotetext{
${ }^{43}$ Marliana, Op.,cit. hlm.232.

${ }^{44}$ Ibid.

45 http://manunggalkusumawardaya.wordpress.com/2010/07/07/perlindungan-terhadap-anakyang- melakukan-tindak-pidana/.( Diakses pada hari rabu, 20 februari 2013 pukul 12.40 wib).
} 
justice sangat membantu sukses atau tidaknya dalam pelaksanaan. ${ }^{46}$

d) Keberhasilan dari proses restroratif justice sangat tergantung dari pihak keluarga yang menjadi tempat anak dikembalikan

Hal ini disebabkan anak pelaku merupakan tanggung jawab dari orang tuanya, jadi pengawasan dari orang tua dan keluarga untuk mengubah perilaku anak dari perilaku melanggar (offence behavior) dapat dijadikan faktor penentu yang cukup berarti. ${ }^{47}$ Ketika orang tua atau keluarga pelaku tidak menghiraukan perilaku anaknya setelah diversi dilakukan (apakah pelaku menyesal atau tidak), maka restroratif belum bisa dikatakan berhasil, karena bisa saja terjadi re-offending atau pelanggaran kembali oleh pelaku.

e) Seringnya terjadi re-offending atau pelanggaran kembali oleh pelaku yang telah menjalani restroratif justice

Inilah yang menjadi dilematis dalam penyelesaian secara diversi dan restroratif justice. Di mana cara penyelesaian seperti ini memiliki kelemahan yakni terjadi re-offending atau pelanggaran kembali oleh pelaku. Dari hasil penelitian Graffith pada tahun 1999 di negara bagian Victoria, Australia, kasus yang sering terjadi adalah terjadinya pengulangan pelanggaran yang dilakukan pelaku setelah conferencing, di mana tidak terdapat perbedaan yang cukup berarti ketika pelaku anak melalui proses restroratif justice atau pemenjaraan (probation). Tapi perbandingan jumlah re-offending setelah restroratif justice atau melalui pemeriksaan pengadilan tidaklah serta merta menunjukkan kemandulan restroratif justice untuk mencegah pelaku reoffending, karena masih ada faktor-faktor lain yang menjadi penyebab reoffending dari proses restroratif justice. ${ }^{48}$

f) Kurangnya pemahaman masyarakat tentang proses restroratif justice dan tujuannya serta kepercayaan terhadap petugas pelaksananya

Penyelesaian tindak pidana yang dilakukan anak melalui kebijakan diversi dan restroratif justice membawa partisipasi masyarakat dan mediator sebagai salah satu komponen selain aparat penegak hukum dalam sistem peradilan pidana. Namun dalam hal ini masyarakat kurang mengerti tentang rerstroratif justice dan tujuannya sehingga terkadang masyarakat tidak mau ikut berperan dalam melakukan restroratif justice.

Padahal peran masyarakat di sini sangat diperlukan, di mana masyarakat memiliki peran yakni memberikan aspirasinya dalam pelaksanaan proses restroratif justice yaitu mengusahakan agar dapat mengembalikan tatanan masyarakat yang terganggu akibat pelanggaran yang dilakukan pelaku dan mengembalikan korban dan pelaku ke dalam

\footnotetext{
${ }^{46}$ Ibid.

${ }^{47}$ Ibid. hlm.231.

${ }^{48}$ Ibid. hlm.231.
} 
wadahnya semula yaitu keluarga dan lingkungannya. ${ }^{49}$ Adanya kesulitan untuk membuat rasa percaya masyarakat terhadap pelaksanaan restroratif justice pada kasus-kasus yang berat. Selain itu, alasan adanya tindakan residivis oleh pelaku anak setelah menjalani proses restroratif justice membuat pertanyaan masyarakat apabila harus mengulangi proses tersebut berapa kali terhadap pelaku yang sama. ${ }^{50}$

2) Kelebihan pemeriksaan perkara anak yang berhadapan dengan hukum di pengadilan anak di dalam Undang-Undang Nomor 11 Tahun 1997 tentang Pengadilan Anak

Dalam Undang-Undang Nomor 11 Tahun 1997 tentang Pengadilan Anak terkait pemeriksaan perkara anak yang berkonflik dengan hukum menekankan penyelesaian melalui jalur di luar pengadilan (diversi) melalui proses restroratif justice. Adapun keunggulan mediasi penal yaitu dapat menjadi ujung tombak dalam reformasi hukum di Indonesia, karena selaras, sesuai dengan budaya Indonesia, yang mengutamakan musyawarah dan mufakat dalam menyelesaikan segala masalah yang mengguntungkan baik dari pihak pelaku maupun korban.

Secara terperinci kelebihan dari pemeriksaan perkara anak secara diversi melalui proses restroratif justice adalah $:^{51}$

i. waktu yang relatif lebih singkat;

ii. menghindarkan anak mengikuti proses peradilan dan penahanan;

iii. mengurangi beban kerja polisi, jaksa, rutan, pengadilan dan lapas;

iv. menghemat keuangan negara;

v. berkurangnya jumlah anak-anak yang divonis penjara;

vi. menjauhkan anak dari pengaruh dan implikasi negatif dari proses peradilan menghapuskan stigma/cap sebagai penjahat dan mengembalikan anak menjadi manusia normal sehingga diharapkan dapat berguna kelak;

vii. tidak menimbulkan dendam karena pelaku telah dimaafkan korban;

viii. korban dapat cepat mendapat ganti kerugian;

ix. diversi dapat mendorong anak untuk bertanggung jawab atas perbuatannya; dan

x. memberdayakan orang tua, korban dan masyarakat ikut serta dalam proses penyelesaian tindak pidana untuk mengatasi kenakalan anak.

\section{Penutup}

\section{Kesimpulan}

\footnotetext{
${ }^{49}$ Ibid. hlm.230.

${ }^{50}$ Ibid. hlm.229.

$51 \quad 51 \mathrm{http}: / /$ pengacaraonlinecom-diversi.blogspot.com/2012/03/html.(Diakases $\quad$ sabtu, 09 februari 2013 pukul09.40 wib).
} 
a. Pengaturan pemeriksaan perkara anak yang berhadapan dengan hukum $(\mathrm{ABH})$ di Pengadilan Anak di dalam Undang-Undang Nomor 3 Tahun 1997 tentang Pengadilan Anak (UU Pengadilan Anak) dengan UndangUndang Nomor 11 Tahun 2012 tentang Sistem Peradilan Pidana Anak (UU SPPA) yaitu UU Pengadilan Anak menentukan bahwa dalam menangani perkara $\mathrm{ABH}$ di Pengadilan hanya menerapkan aturan pemeriksaan secara formal yakni melalui proses persidangan. Ketentuan pemeriksaan perkara $\mathrm{ABH}$ diatur secara khusus dalam BAB IV Paragraf 4 Pasal 55 sampai dengan Pasal 59. Sementara di dalam UU SSPA diatur bahwa sebelum melewati proses persidangan hakim wajib mengupayakan penyelesaian perkara anak secara diversi atau disebut juga penyelesaian perkara anak di luar pengadilan (informal). Sebagaimana yang disebutkan dalam Pasal 52 Ayat (2), bahwa: "Hakim wajib mengupayakan diversi paling lama 7 (tujuh) hari setelah ditetapkan oleh Ketua Pengadilan Negeri sebagai Hakim". Selanjutnya perkara ABH akan lanjut ke tahap persidangan di pengadilan apabila dalam penyelesaian secara diversi tidak berhasil dilaksanakan (Pasal 52 Ayat (6) UU SPPA).

b. Kelemahan dan Kelebihan pemeriksaan perkara ABH di Pengadilan Anak di dalam Undang-Undang Nomor 3 Tahun 1997 tentang Pengadilan Anak (UU Pengadilan Anak) dengan Undang-Undang nomor 11 tahun 2012 tentang Sistem Peradilan Pidana Anak adalah:

1) Kelemahan pemeriksaan Perkara anak di pengadilan di dalam UU Pengadilan Anak UU Pengadilan Anak mengatur pemeriksaan perkara anak melalui mekanisme formal yakni melalui peradilan. Adapun kelemahan dari pemeriksaan perkara anak melalui mekanisme persidangan di Pengadilan adalah: prosesnya panjang dan biaya mahal, anak akan kehilangan kebebasan akibat ditahan atau dijatuhi hukuman penjara, anak mengalami beban psikis akibat penilaian/label jelek dari masyarakat, dan sering terjadi pengulangan atau penghukuman kembali (reconviction rate) terhadap pelaku.

2) Kelebihan pemeriksaan perkara anak yang berhadapan dengan hukum di pengadilan anak di dalam Undang-Undang Nomor 3 Tahun 1997 tentang Pengadilan Anak adalah proses peradilan dapat berfungsi sebagai preventif (sebagai upaya menanggulangi kejahatan untuk yang akan datang dan upaya represif (sebagai efek jera terhadap pelaku).

3) Kelemahan pemeriksaan perkara anak yang berhadapan dengan hukum di pengadilan anak di dalam UU Sistem peradilan Pidana Anak

UU Sistem Peradilan Pidana Anak menentukan bahwa sebelum melewati proses persidangan hakim wajib mengupayakan penyelesaian perkara anak secara diversi. Adapun kelemahan 
pemeriksaan perkara anak secara diversi melalui restroratif justice adalah sulit untuk dilaksanakan jika tindak pidana yang dilakukan oleh pelaku diancam dengan pidana berat karena susah mendapatkan persetujuan korban/keluarga korban, keberhasilan dari proses restroratif justice juga sangat tergantung dari pihak keluarga yang menjadi tempat anak dikembalikan artinya jika perkembangan anak tidak di pantau oleh keluarga maka implikasinya sering terjadi reoffending atau pelanggaran kembali oleh pelaku yang telah menjalani restroratif justice, terakhir kurangnya pemahaman masyarakat tentang proses restroratif justice serta kepercayaan terhadap petugas pelaksananya.

4) Kelebihan pemeriksaan perkara anak yang berhadapan dengan hukum di pengadilan anak di dalam UU Sistem peradilan Pidana Anak yakni berkurangnya jumlah anak-anak yang divonis penjara, dapat menghapuskan stigma/label jahat kepada anak pelaku serta dapat menjauhkan anak dari pengaruh dan implikasi negatif dari proses peradilan.

\section{Saran}

Merekomendasikan agar praktek diversi melalui proses restroratif justice untuk diperluas tidak hanya terhadap tindak pidana yang diancam maksimal 7 (tujuh tahun), karena bagaimanapun ini merupakan salah satu bentuk pembatasan HAM anak pelaku. Merekomendasikan agar penegak hukum memberikan suasana yang kondusif untuk terjadinya penyelesaian non litigasi. Selain itu dalam bidang legislasi, perlu diwujudkan adanya semacam peraturan pelaksanaan yang bersifat teknis untuk menunjang penyelesaian secara non litigasi ini.

Diversi melalui proses restroratif justice perlu disosialisasikan kepada masyarakat luas, agar masyarakat paham tentang proses restroratif justice dan tujuannya serta dapat memberikan kontribusi dalam pelaksanaan diversi guna untuk mengembalikan tatanan masyarakat yang terganggu akibat pelanggaran yang dilakukan pelaku.

Penting pula diperhatikan agar masyarakat dapat menghilangkan budaya yang memberikan cap/labelisasi buruk terus menerus terhadap anak pelaku tindak pidana. Masyarakat hendaknya menerima anak pelaku tindak pidana, agar ia kembali dapat menemukan ruangnya di dalam masyarakat.

Meskipun perbandingan jumlah re-offending (pelanggaran kembali) yang diselesaikan melalui diversi dengan pengadilan tidak ada perubahan namun diversi tidaklah serta merta menunjukkan kemandulan restroratif justice untuk mencegah pelaku re-offending karena masih ada faktor-faktor lain yang menjadi penyebab re-offending. Untuk menghindari re-offending, salah satu faktornya adalah orang tua harus lebih memperhatikan anak, serta 
membimbing dan memantau perilaku anak karena keluarga adalah tempat pertama kali si anak tumbuh dan berkembang.

\section{Daftar Pustaka}

\section{A. Buku}

Marliana, 2009. Peradilan Pidana Anak di Indonesia (Pengembangan Konsep Diversi dan Restrorative Justice), Bandung: Refika Aditama.

Nashriana, Perlindungan Hukum Pidana Bagi Anak di Indonesia, Jakarta: Raja Grafindo Persada.

Prinst, Darwan, 1997. Hukum Anak Indonesia, Bandung: Citra Aditya Bakti. Soeaidy, Sholeh dan Zulkhair, 2001. Dasar Hukum Perlindungan Anak, Jakarta : Novindo Pustaka mandiri.

Soetedjo, Wagiati, 2007. Hukum Pidana Anak, Bandung: Refika Aditama.

\section{B. Peraturan Perundaang-undangan}

Undang-Undang Republik Indonesia Nomor 4 Tahun 1979 Tentang Kesejahteraan Anak, Lembaran Negara Republik Indonesia Tahun 1979 Nomor 32, Tambahan Lembaran Negara Republik Indonesia Nomor 3143.

Undang-Undang Republik Indonesia Nomor 3 tahun 1997 Tentang Peradilan Anak, Lembaran Negara Republik Indonesia Tahun 1997 Nomor 3 Tambahan Lembaran Negara Republik Indonesia Nomor 3668.

Undang-Undang Republik Indonesia Nomor 23 Tahun 2002 Tentang Perlindungan Anak, Lembaran Negara Republik Indonesia Tahun 2002 Nomor 109, Tambahan Lembaran Negara Republik Indonesia Nomor 4235.

Undang-Undang Republik Indonesia Nomor 11 Tahun 2012 Tentang Sistem Peradilan.

Lembaran Negara Republik Indonesia Tahun 2012 Nomor 153, Tambahan

Lembaran Negara Republik Indonesia Nomor 5332.

Keputusan Perseiden Nomor 36 Tahun 1990 Tentang Pengesahan Convention on the Rights of the Child (Konvensi tentang Hak-Hak Anak), Lembaran Negara Republik Indonesia Tahun 1990 Nomor 57.

Peraturan Menteri Negara Pemberdayaan Perempuan dan Perlindungan Anak Nomor 15 tahun 2010 Tentang Pedoman Umum Penanganan Anak Yang Berhadapan Dengan Hukum.

Keputusan Bersama Ketua Mahkamah Agung RI, Jaksa Agung RI, Kepala Kepolisian RI, Menteri Hukum dan HAM RI, Menteri Sosial RI, 
Menteri Negara Pemberdayaan Perempuan dan Perlindungan Anak Tahun 2009 Tentang Penanganan Anak Yang Berhadapan Dengan Hukum. 